\title{
CREATIVITY OF THE POPULATION AS A KEY TO REGIONAL SUSTAINABILITY AND ENTREPRENEURSHIP DEVELOPMENT
}

\author{
Baiba Rivza1 ${ }^{1}$, Dr.hab.oec.; Karlis Markus², Mg.sc.soc. and \\ Maiga Kruzmetra ${ }^{3}$, senior researcher \\ 1,2,3 Latvia University of Life Sciences and Technologies
}

\begin{abstract}
Every capable, creative person must be able to create and prove his ideas in every region of Latvia. Development of creativity of the population will increase human capital, which determines the quality of life of the country's population in general, but mainly in the regions. Promoting the development of human capital requires cooperation between the population and educational institutions, the implementation of which presupposes the digitalization of information exchange, the introduction of information platforms, the sharing of knowledge and the recognition of ideas. By developing the creativity of the population, it is possible to promote the advantages of each region, which in Zemgale would be associated mainly with the development of bioeconomy and eco-products and services. One of the tools to promote creativity would be the creation of regional university business incubators, which would encourage the involvement of creative people in the creation of eco-products and services.
\end{abstract}

Key words: Creative person; regional development; commercialization of ideas.

JEL code: C31, R11

\section{Introduction}

The aim of the present work is to analyse the possibilities of regional development through the establishment of tools in Latvia University of Life Sciences and Technologies that will develop the creativity and entrepreneurship of the population in Zemgale region. To analyse this, the authors hypothesize: An effective tool for the development of the creative population, providing social and economic benefits in the regions of Latvia, is specialized university business incubators. Latvia University of Life Sciences and Technologies intends to create a bioeconomy business incubator that will involve local people in the commercialization of their ideas.

The monographic or descriptive method is used to interpret the research results based on the existing scientific knowledge and theories as well as the legal framework in Latvia.

\section{Research results and discussion}

Today, capital is no longer just money or resources, but above all a human being with his or her unique and creative abilities. "Our main capital is people - their skills, knowledge and talents. Our capital is nature, environment and space of Latvia. Also, cultural heritage and creativity, the ability to co-operate and to do something jointly, which would be impossible to do individually, is our capital and the source of growth" (Saeima of the Republic of Latvia, 2010). The development of Latvia as European Union country requires significant investment in the creation of knowledgeable and creative people, because human capital is the most important resource for fastest growth, as other resources are limited. By creating an environment for knowledge transfer and creativity, it is possible to develop an environment for entrepreneurship in the regions of Latvia. By using regional advantages, many new business ideas can be commercialized. The only prerequisite is that people living in the regions outside the largest cities have the right tools for entrepreneurship.

"Nowadays innovation is not attributed only to high technologies, but also to the creation and introduction of new ideas in every field of activities, so it becomes more important that the competitiveness of countries involves increasingly large number of inhabitants in the process of creative activity. Economic

1 Baiba Rivza, phone +371 29254469, e-mail: baiba.rivza@llu.Iv

2 Kārlis Markus, phone +37120836000 , e-mail: karlis@jic.lv

3 Maiga Kruzmetra, phone +371 26395355, e-mail: swonders@apollo.Iv 
system with higher social mobility means also higher creativity of the society because each capable, creative person even from the lowest classes of the society has an opportunity to create and prove his or her ideas" (Saeima of the Republic of Latvia, 2010).

In recent years a large part of the Latvian population has moved to the big cities and also out of the country. These people have travelled mainly for the higher salaries and better life. This movement of labor means that talented and skilled people are flocking to global development centres where they have the opportunity to get a higher salary or an environment for personal growth and business development.

National Development Plan of Latvia for 2021-2027 Priority 2 "Knowledge and Skills for Personal and National Growth" determines these goals:

"A knowledgeable, inclusive and creative society in an efficient, innovative and productive economy" and "Quality education for the acquisition of knowledge and skills applicable in business and daily -life for every inhabitant of the country".

These goals are in line with the EU's general policies on regional development following the EU priorities in integration: e.g. in jobs and growth, digital single market, energy and climate, industrial development, migration issues, etc. However, there are some spheres that needed additional attention and common efforts from the sub-regional communities' perspectives. The regional "influences" have grown from the lack of state governance to take a proper stand on local issues.

In order to achieve the goals, the conditions set by the authors must be ensured.

- More and more people must be involved in the process; especially users of services and products, interoperability, openness, knowledge and creativity are the keys to success.

- Global experience shows that around $73 \%$ of industrial innovations are not turned into successful industrial products, not because they are not technologically excellent, but because they do not meet the needs of users. This means that feedback from potential users must be provided during the product development process.

- Information platforms should be used for knowledge transfer and release of ideas.

- Knowledge, universities and research play an increasingly important role in today's economy. This means that educational and research institutions need to create and maintain their own platforms through which knowledge becomes accessible to Latvian businesses and young entrepreneurs, especially in the regions.

- Globalization offers new opportunities for creative and enterprising people to choose cities and countries where they can start a successful business. We must promote Latvian regions for new business opportunities.

- The government plays a key role in creating and maintaining a framework in which businesses can innovate, as well as in providing direct support. The government should establish business support mechanisms that support start-ups in all regions of Latvia.

A European strategy for smart, sustainable and inclusive growth says: "At national level, Member States will need: ... to focus school curricula on creativity, innovation, and entrepreneurship" (European Commission, 2010)

According to the regional officials, the Baltic States are facing a "profound change" in the Baltic Sea Region (BSR) governance based on "closer cooperation, good action plans and communication"; in fact, it is about "a new narrative for the region". Strikingly enough, these "changes" have not been fully integrated into the modern global and European trends, e.g. sustainability, bio- and circular-economy, digitalisation and scientific innovations, to name a few. 
The changes include drafting a new type of a strategy with, e.g. circular economy issues and optimal action plans for the regions and local communities in circular and bio-economies' practical implementation.

An efficient sub-regional cooperation in BSR is balancing between the national political economy's guidance and that of the regional-EU's planning: e.g. less activity in the former could result in more active part in the latter, and vice versa!

Coordinated transfer of skills and knowledge in regional entrepreneurship and business development will develop the creative society and strengthen the economy in Latvia. Now we see economically growing businesses mainly in or near the largest cities in Latvia. To create regional business development we need to use already existing opportunities such as universities with their infrastructure, municipalities, Magnetic Latvia 15 regional incubators, 9 Rural Support Service Customer service centres, 26 branches of Latvian Rural Consultation and Education Centre, financial institution Altum 21 branches and Latvian Chamber of Commerce and Industry with 5 regional centres. These business support structures can be used for business start-ups in Latvian regions, but we need to ensure information transfer between these authorities.

We can see that there are already authorities working separately in Latvian regions, but unfortunately they do not focus on the benefits of the region such as organic or bio products. Luck and the fragmentation of information is also a reason why people do not use the local opportunities offered by the existing authorities.

The authors believe that a regional specialized business incubator operated by the local university is an effective tool for commercializing ideas and support businesses.

"...business incubators have positive effects to regional innovation performance through its basic, finance and incubation capacities. In this sense, managers of business incubators and policy makers should emphasize more on the cultivation of those specific capacities to develop business incubators further. Moreover, this study indicates that regional communication infrastructure investments are essential to facilitate the positive impacts of business incubators on regional innovation performance. Effective investments into the communication infrastructure would not only help improve the performance of business incubators, but also accelerate the transfer of outputs of business incubators into the wider regional innovation performance. Therefore, effective policies introduction and streamlined procedures to facilitate communication infrastructure development should be one of the most important focus of policy makers" (Z.Wang, Q.He, S.Xia, D.Sarpong,A.Xiong,G.Maas, 2020).

University business incubators used to be and are now mainly interpreted as helping students and researchers to develop scientific start-ups by providing necessary business development services to students and researchers (E. Rogova, 2014). But today we see many new ideas such as entrepreneurial university, which of course include the tools as business incubators for all business start-ups. Implementation of Entrepreneurial University focuses on education and interaction of creativity, which will help to raise a generation of entrepreneurs. Universities with their laboratories and scientific infrastructure and knowledge can offer many advantages to potential new entrepreneurs, but also the simple transfer of knowledge and education can be crucial for the potential entrepreneur.

"Many incubators around the world are supported by universities. Others are making initiatives to link up with universities and higher education institutions to get the revenues and returns from its academic nature. Lately, university incubators became a type of incubator evolution and more supportive for entrepreneurs than other types of incubators." (N. A. Hassan, 2020).

In Latvia, there are 11 business incubators operated by Latvia higher educational institutions. The research of Veronika Bikse, Inese Lusena-Ezera, Baiba Rivza and Tatjana Volkova shows that: 
"Overall, the authors can conclude that the contribution of the Latvian universities and student business incubators to ensure sustainable education is essential. In cooperation with business incubators, the universities contribute to the engagement of new entrepreneurs in business; incubated enterprises create new jobs and develop products of various kinds, and these in turn play a considerable role in the sustainable higher education development. Nevertheless, according to the survey, new entrepreneurs need assistance in creating networks of cooperation with various institutions, particularly local governments, as local government support as well as cooperation with universities - upon which knowledge transfer to production, innovation and eco-entrepreneurship is dependent - are important to the new entrepreneurs, nowadays the most important prerequisite for economic growth." (V. Bikse, I. Lusena-Ezera, B. Rivza, T. Volkova, 2016).

However, to date none of Latvia's higher education institutions or Magnetic Latvia incubators specialize in specific regional development or the development of e.g. bioeconomy products. For example, the Magnetic Latvia business incubators of the Investment and Development Agency of Latvian provide basic business incubator services without focusing on the priorities or strengths of a specific region.

The authors' research focuses on increasing the creativity of people in Zemgale region, leading to the commercialization of their ideas, through close cooperation with the organizational units of Latvia University of Life Sciences and Technologies and obtaining direct or indirect financial support from national institutions for the creation of a specialized business incubator. Accordingly, we can explore the idea of establishing the bioeconomy business incubator in Latvia University of Life Sciences and Technologies.

According to the data from Central Statistical Bureau Republic of Latvia in Fig. 1 below, we can see that the number of economically active enterprises in Zemgale is the largest by the number of employees 15117 enterprises, in the small or micro enterprises.

According to the Law on the Annual Financial Statements and Consolidated Financial Statements: " $A$ micro-entity is a small undertaking which on the balance sheet date does not exceed at least two of three limit values of the criteria referred to in this Paragraph:

1) balance sheet total - EUR 350 000;

2) net turnover - EUR 700 000;

3) average number of employees during the reporting year - 10."

This shows that the main activities in Zemgale region of Latvia are carried out by small businesses, which is our target group for further development.

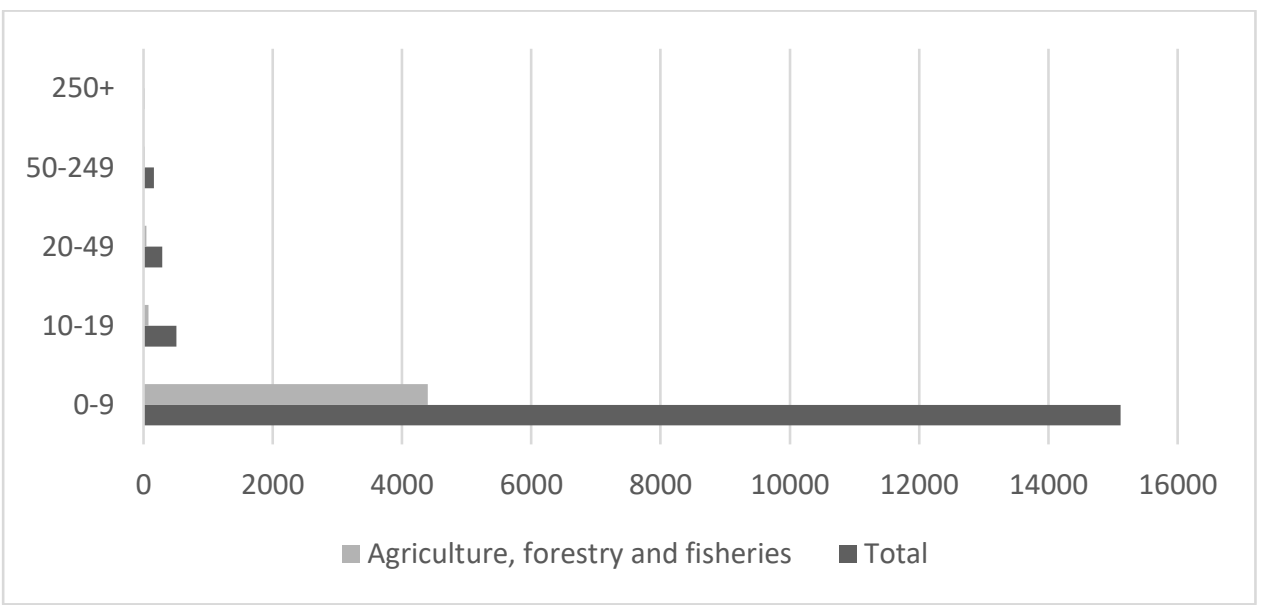

Source: author's calculations based on Central Statistical Bureau Republic of Latvia data

Fig. 1. Number of economically active enterprises in Zemgale by number of employees 
Fig. 2 below shows the occupied jobs in Zemgale by type of occupation, with the population mainly employed in sectors such as agriculture, manufacturing, construction, wholesale and retail trade, health and social services and also to a large extent in education.

These data show that focusing on small business development in a specific area where the region's main activities take place is the right way to improve regional economic activity and social well-being in general.

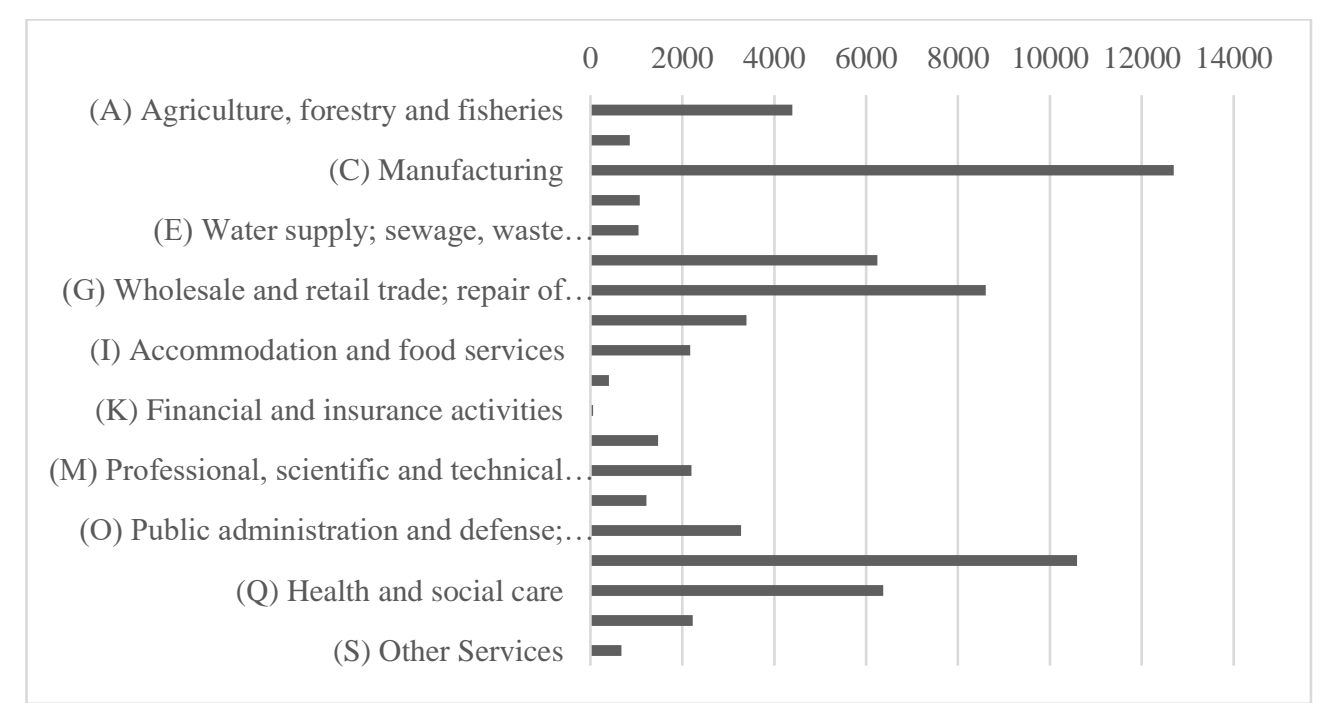

Source: author's calculations based on Central Statistical Bureau Republic of Latvia data

Fig. 2. Occupied jobs in Zemgale by type of activity at the end of the $3^{\text {rd }}$ quarter of $\mathbf{2 0 2 0}$

The authors' idea intends to shift regional culture and business towards ecosystem philosophy. In Latvia, the knowledge-intensive bioeconomy is one of the nationally defined areas of smart specialization (RIS3). The Latvian Bioeconomy Strategy for 2030 has been developed. The implementation of specialized business incubator in Latvia University of Life Sciences and Technologies would make a significant contribution to the local business possibilities, expanding the knowledge base of university and opportunities for the creation and commercialization of new bioeconomy products and creating a new knowledge.

To achieve that, it is planned to focus on knowledge transfer and the development of new businesses through an IT platform, with an emphasis on a virtual environment which, due to the spread of COVID-19, would enable the development of various products distantly. This business incubator would also serve as a knowledge transformation platform for other regions. The platform will provide transfer at team and individual levels, improve international cooperation and will support locals with necessary education for further business development especially in areas related to regional advantages.

Also the involved entrepreneurs will benefit from network of educational institutions and their scientifically works. This network of educational institutions and entrepreneurs will effectively manage idea commercialization and fundraising. Latvian education system will be more related to business development with its educational competence.

For the establishment of such regional business incubators, significant public investment is needed. The government shall develop the program for university specialized business incubator establishment and funding.

Also municipalities shall participate and educate local people of all ages to upgrade their digital skills achieve significant gains from business opportunities. 
The mentioned platform shall also share access to fundraising opportunities. This requires funding in the first phase through business incubators and after successful approval of ideas for further financial incentives.

Further economic growth and a higher standard of living for the people of Latvia depend on the ability to create new businesses using creative ideas for business start-ups in local regions but with potential world markets. The rapidly changing environment, increases business opportunities in the creation of ecological products. Such products as Purenn, Kiwi Cosmetics, Rudolfs are some of the successful examples from Zemgale region that have established long term business with ecological products that are produced locally but have a great potential in the world market.

Providing local support will allow small Latvian companies to compete in international markets and integrate into global value chains with higher value added products, thereby increasing export. The innovative eco ideas will be commercialized and developed by private, public and academic cooperation that aligns research and innovation capacity with business needs.

\section{Conclusions, proposals, recommendations}

1) Business incubators are recognized as a tool for developing and stimulating the economy in regions and situations where the market itself does not provide the environment and conditions for business start-ups. This is particularly the case in the aftermath of a pandemic and could be especially important if the COVID-19 pandemic lasts for a long time. At the beginning of this century, business incubators have become important places for technological advancement, information exchange and innovation. They attract financial resources and serve as homes for young entrepreneurs.

2) By developing the creativity of the population, it is possible to promote the benefits of each region, which in Zemgale would be mainly associated with the development of bioeconomy and eco-products and services. Creative people will establish new start-ups and provide recognition and visibility of new/innovative bioeconomy products in the Baltics and the European Union, increasing the value and efficiency of Latvia's natural capital.

3) The establishment of the Bioeconomy Business Incubator in Latvia University of Life Sciences and Technologies will serve to regional consolidation of innovations in bioeconomy-related products, including development and commercialization of goods and services in the bioeconomy industries, which would contribute to regional initiative and reduce COVID-19 risks by concentrating business expansion in less burdened regions.

4) The established LLU business incubator would also serve as a knowledge transformation platform for other regions. To achieve this, we need to focus on knowledge transfer and new business development through a IT platform, with a focus on a virtual environment which, due to the spread of COVID-19, would enable the development of various products distantly.

5) The methodological framework for this research should be established and presented to national institutions for fundraising.

\section{Acknowledgement}

The paper was supported by the NATIONAL RESEARCH PROGRAMME "LATVIAN HERITAGE AND FUTURE CHALLENGES FOR THE SUSTAINABILITY OF THE STATE" project "CHALLENGES FOR THE LATVIAN STATE AND SOCIETY AND THE SOLUTIONS IN INTERNATIONAL CONTEXT (INTERFRAME-LV)" 


\section{Bibliography}

1. EUROPE 2020, A Strategy for Smart, Sustainable and Inclusive Growth, (COM (2010) 2020), European Commission.

2. Law on the Annual Financial Statements and Consolidated Financial Statements, into force from 3 January 2018, Saeima of the Republic of Latvia.

3. National Development Plan of Latvia for 2021-2027, approved on 2 July 2020 by decision of the Saeima of the Republic of Latvia No. 418/Lm13.

4. Sustainable Development Strategy until 2030 of Latvia (2010), Saeima of the Republic of Latvia

5. Bikse, V., Lusena-Ezera, I., Rivza, B. and Volkova, T. (2016). The Transformation of Traditional Universities into Entrepreneurial Universities to Ensure Sustainable Higher Education. Journal of Teacher Education for Sustainability, vol. 18, no. 2, pp. 75-88.

6. Chandra, A., Alejandra, M. and Silva, M. (2012), Business Incubation in Chile: Development, Financing and Financial services. Journal of Technology Management and Innovation, Vol. 7 No. 2, pp. 1-13.

7. Doncean, M. (2013). Business Incubators for Young Enterpreneurs, A Model For the Romania-Ukraine-Republic of Moldova Cross-Border Cooperation. Lucrari Ştiinţifice - vol. 56 (2), seria Agronomie, pp.217-221.

8. Ettorre, J. (2019). Hope in the Heartland A Business Incubator is Helping Youngstown, Ohio Believe in Itself Again. The U.S. News \& World Report, L.P.

9. Fern, D., Arruti, A., Markuerkiaga, L. and Saenz, N. (2018), "The Entrepreneurial University: a Selection of Good Practices". Journal of Entrepreneurship Education, Vol. 21, pp. 1-17.

10. Geipele, I., Pukite, I., Kauškale, L. (2016). Importance of business incubators for new business and its development in Latvia. Proceedings of the International Conference on Industrial Engineering and Operations Management, 8-10 March 2016, pp. 1199-1206.

11. Hassan, N.A. (2020). University Business Incubators as a Tool for Accelerating Entrepreneurship: Theoretical Perspective. Review of Economics and Political Science Emerald Publishing Limited e-ISSN: 2631-3561 p-ISSN: 2356-9980 DOI 10.1108/REPS-10-2019-0142.

12. Helmer, J. (2016). Operation Innovation. Colleges and Universities are Launching Business Incubators to Instill the Entrepreneurial Spirit-and so much more-on campuses. www.universitybusiness.com, July 2016 | 29.

13. Jermolajeva, E., Cingule-Vinogradova, S. (2012). Potential of Latgale Region and Directions of the Development. Economic Science for Rural Development Conference Proceedings. Issue 27, pp. 100-106.

14. Lūsēna-Ezera, I., Līduma, D., Eglinš-Eglītis, A. (2018). Necessity of Work Team in Manufacturing Branch Startup Enterprises in Latvia. Proceedings of the 32nd International Business Information Management Association Conference, IBIMA 2018 - Vision 2020: Sustainable Economic Development and Application of Innovation Management from Regional Expansion to Global Growth, pp. 3561-3569.

15. Mavi, R., Gheibdoust, H., Khanfar, A. and Mavi, M. (2019), Ranking Factors Influencing Strategic Management of University Business Incubators with ANP, Management Decision ISSN: 0025-1747.

16. Pukite, I., Geipele, I. (2015). Business Incubatirs as a Financial Instrument for New Business Development. Proceedings of the 2015 International Conference "Economic Science for Rural Development" No39 Jelgava, LLU ESAF, pp. 124-133.

17. Rogova, E. (2014). The Effectiveness of Business Incubators as the Element of the Universities' Spin-off Strategy in Russia. International Journal of Technology Management \& Sustainable Development Volume 13 Number 3, pp.265-281.

18. Spruksts, E. (2014). Factors Infuencing Starting up a Business in Latvia. Economic Science for Rural Development No. 36, pp.147-154.

19. Pigozne, T., Luka, I. and Surikova, S. (2019). Promoting Youth Entrepreneurship and Employability through Non-Formal and Informal Learning: The Latvia Case. C.E.P.S Journal, Vol.9, No.4, (DOI: 10.26529/cepsj.303) pp. $129-150$.

20. Wang, Z., He, Q., Xia, S., Sarpong, D., Xiong, A., Maas, G. (2020). Capacities of business incubator and regional innovation performance. Technological Forecasting and Social Change, Elsevier, September 2020 (https://doi.org/10.1016/j.techfore.2020.120125). 